\title{
Brasergasilus mamorensis sp. n. (COPEPODA: ERGASILIDAE) FROM THE NASAL CAVITIES OF Hydrolycus pectoralis (GUENTHER, 1866) (CHARACIFORMES: CYNODONTIDAE) FROM THE BRAZILIAN AMAZON, AND CONSIDERATIONS ABOUT ABERGASILINAE.
}

\author{
Angela Maria Bezerra VARELLA ${ }^{1}$, José Celso de Oliveira MALTA ${ }^{1}$
}

\begin{abstract}
Brasergasilus mamorensis sp. n., collected from the nasal cavities of Hydrolycus pectoralis (Guenther, 1866) in the Mamoré River, Rondonia State, Brazil, is described. This is the first time that a species from the genus Brasergasilus has been collected in the nasal cavities. This new species is the only one that has a spine on the first segment of the antenna, a simple seta on the basipodites of the first three pairs of legs and one pair of vestigial legs (leg 5 ) on the sixth thoracic somite.
\end{abstract}

Key-words: Copepoda, Poecilostomatoida, Fish Parasites, Mamoré River.

Brasergasilus mamorensis sp. n. (Copepoda: Ergasilidae) das Fossas Nasais de Hydrolycus pectoralis (Guenther, 1866) (Characiformes: Cynodontidae) da Amazônia Brasileira e Considerações Sobre Abergasilinae.

RESUMO - Brasergasilus mamorensis sp. n. é descrito. Foi coletado das fossas nasais de Hydrolycus pectoralis (Guenther, 1866) no rio Mamoré, Estado de Rondônia, Brasil. Esta é a primeira vez que uma espécie do gênero Brasergasilus é coletada parasitando as fossas nasais de seu hospedeiro. A nova espécie é a única que apresenta um espinho no primeiro segmento da antena, uma seta simples nos basipóditos dos três primeiros pares de pernas e um par de pernas vestigiais (perna 5) no sexto somito torácico.

Palavras-chave: Copepoda, Poecilostomatoida, parasita de peixes, rio Mamoré.

\section{INTRODUCTION}

South American freshwater fish parasitic copepod species are included in 4 families and 13 genera. Family Ergasilidae includes 8 genera: Ergasilus Nordmann, 1832; Acusicola Cressey, 1970; Brasergasilus Thatcher \& Boeger, 1983; Amplexibranchius Thatcher \& Paredes, 1985; Rhinergasilus Boeger \& Thatcher, 1988; Prehendorastrus Boeger \& Thatcher, 1990; Miracetyma Malta, 1993 and Pindapixara Malta, 1994. Family Vaigamidae has 4 genera: Vaigamus Thatcher \& Robertson, 1984; Gamidactylus Thatcher \& Boeger, 1984;
Gamispinus Thatcher \& Boeger, 1984 and Gamispatulus Thatcher \& Boeger, 1984. Family Therodamasidae has 2 genera: Therodamas Kroyer, 1863 and Amazonicopeus Thatcher, 1986. Family Lernaeidae has 4 genera: Areotrachelus Brian, 1902; Taurocheros Brian, 1924; Perulernaea Thatcher \& Paredes, 1985 and a single species of the genus Lernaea Linnaeus, 1756 (Boxshall et al., 1997; Malta \& Varella, 1998; Thatcher, 1998).

Thatcher \& Boeger (1983) proposed a new subfamily, Abergasilinae including 2 genera, Abergasilus Hewitt, 1977 with 1 species, A. am-

'INPA/CPBA, Laboratório de Parasitologia e Patologia de Peixes - LPP, Caixa Postal 47869011 - 970 Manaus - Amazonas - BRASIL 
plexus, and Brasergasilus with 4 species, because they have the same caracteristics: antenna with 2 segments and a well developed claw, a small body and 3 pairs of legs. The fifth species belonging to the genus Brasergasilus is described in this paper.

\section{MATERIAL AND METHODS}

Fish were captured during an expedition to Rondônia State. The collections were carried out in the Mamoré River, near Surpresa, from September 15 to October 4 1985, during low water. Fish samples were obtained using gillnets. Fish were identified and fork length and weight were recorded. The tissue surrouding the nasal cavities was removed and fixed in $10 \%$ formalin.

The copepods were removed from the nasal cavity tissue by using jets of water and, separated with a dissecting microscope. They were stored in $70 \%$ alcohol. Specimens were stained with a mixture of eosin and orange $\mathrm{G}$ in $95 \%$ ethanol. Permanent preparations were made by dehydrating in phenol, clearing in methyl salicylate, and mounted in balsam (Thatcher, 1991). Drawings were made with the aid of a camera lucida. Measurements were made with an ocular micrometer and are expressed in micrometers. The parasitological terms were expressed according to Margolis et al. (1982) modified by Bush et al. (1997).

Type specimens were deposited in the Collection of the Instituto
Nacional de Pesquisas da Amazônia (INPA-CR), Manaus, Amazonas and in the Museu de Zoologia da Universidade de São Paulo (MZUSP), São Paulo, São Paulo State.

\section{RESULTS}

\section{Brasergasilus mamorensis sp. $\mathbf{n}$.}

Material examined: Holotype: female INPA-CR-625 (slide), from the nasal cavities of Hydrolycus pectoralis (Guenther, 1866) collected in Mamoré River, near Surpresa (1152'S and $\left.64^{\circ} 56^{\prime} \mathrm{W}\right), 25-\mathrm{ix}-1985$. Paratypes: 15 females INPA-CR-626a-p (slides) and 2 females MZUSP 10453a-b (slides), from the nasal cavities of 4 specimens of Hydrolycus pectoralis collected in the same type locality, 25ix-1985. All collected by J.C.O. Malta.

Description: (based on 18 specimens studied and 10 measured (Tabs 1, 2). Cephalothorax (Figs. 1, 2) slightly tapered anteriorly. Head fused with first two thoracic somites. Pigmentation not observed. Thorax of five free somites (Fig. 1), including somites V and VI reduced and genital somite (Fig. 2); fifth somite without appendages, and sixth with 1 vestigial leg on each side. Genital somite subrectangular.

Abdomen of three somites, with thin spinules ventrally at lateral-posterior margins. Each uropod (Figs. 2, 3 ) with one long and one short seta, one long terminal spine and two rows of small ventral spinules, one distal and other median, reaching external margin. 
Table 1. Measurements (mm) of 10 adult females of Brasergasilus mamorensis sp. $\mathbf{n}$., minimum-maximum (mean).

\begin{tabular}{|c|c|c|c|}
\hline \multirow[b]{2}{*}{ Body (less caudal setae) } & Length & \multicolumn{2}{|c|}{ Width } \\
\hline & $432-512 \quad(468)$ & $144-224$ & (195) \\
\hline Cephalothorax & $238-282(262)$ & $144-224$ & (195) \\
\hline \multicolumn{4}{|l|}{ Free thoracic somites } \\
\hline III & $37-52 \quad(45)$ & $111-150$ & $(130)$ \\
\hline IV & $41-56 \quad(47)$ & $74-100$ & $(88)$ \\
\hline V & $6-12(10)$ & $42-57$ & $(48)$ \\
\hline VI & $6-14 \quad(10)$ & $42-60$ & $(48)$ \\
\hline VII (genital) & $34-39 \quad(37)$ & $54-70$ & $(61)$ \\
\hline \multicolumn{4}{|l|}{ Abdominal somites } \\
\hline 1 & $6-14 \quad$ (9) & $30-44$ & $(38)$ \\
\hline II & $4-10 \quad(7)$ & $33-42$ & $(37)$ \\
\hline III & $8-14 \quad(11)$ & $32-42$ & $(37)$ \\
\hline Uropods & $22-27 \quad(24)$ & $14-18$ & $(16)$ \\
\hline Caudal setae & $148-180 \quad(162)$ & & \\
\hline Egg sacs & $136-254 \quad(180)$ & $34-50$ & $(44)$ \\
\hline
\end{tabular}

Table 2. Antennal measurements (mm) of 10 adult females of Brasergasilus mamorensis sp. n., minimum-maximum (mean).

\begin{tabular}{lccc}
\hline & \multicolumn{2}{c}{ Length } & Width \\
\hline $\begin{array}{l}\text { Antennule } \\
\text { Antenna } \\
\text { Segment 1 }\end{array}$ & $72-92(83)$ & $14-20(17)$ \\
& & & \\
Claw & & $40-74(51)$ & $34-47(41)$ \\
& $71-92(82)$ & $28-34(31)$ \\
\end{tabular}

Antennules of six segments (Fig. 4), with 22 simple (aesthetascs) setae. Setal formula per segment: $3-5-$ 3-4-2-5. Antenna two segmenteds (Fig. 5). First segment with distal spine, second segment wide and smooth and claw strongly curved at its two extremities, with an enlargement near to distal pore, giving it the ap- pearance of half an arrow head. Ratios of lengths of segments: 1:1.6:2.2.

Mouthparts (Fig. 6). Mandible bisegmented, with a terminal bifurcate segment with bristles on its distal margin. Short palp, bristled posteriorly. Maxillule absent. Maxilla bi-segmented, distal segment with a bristled tip.

Legs (Figs. 7 - 10 and Tab. 3). 


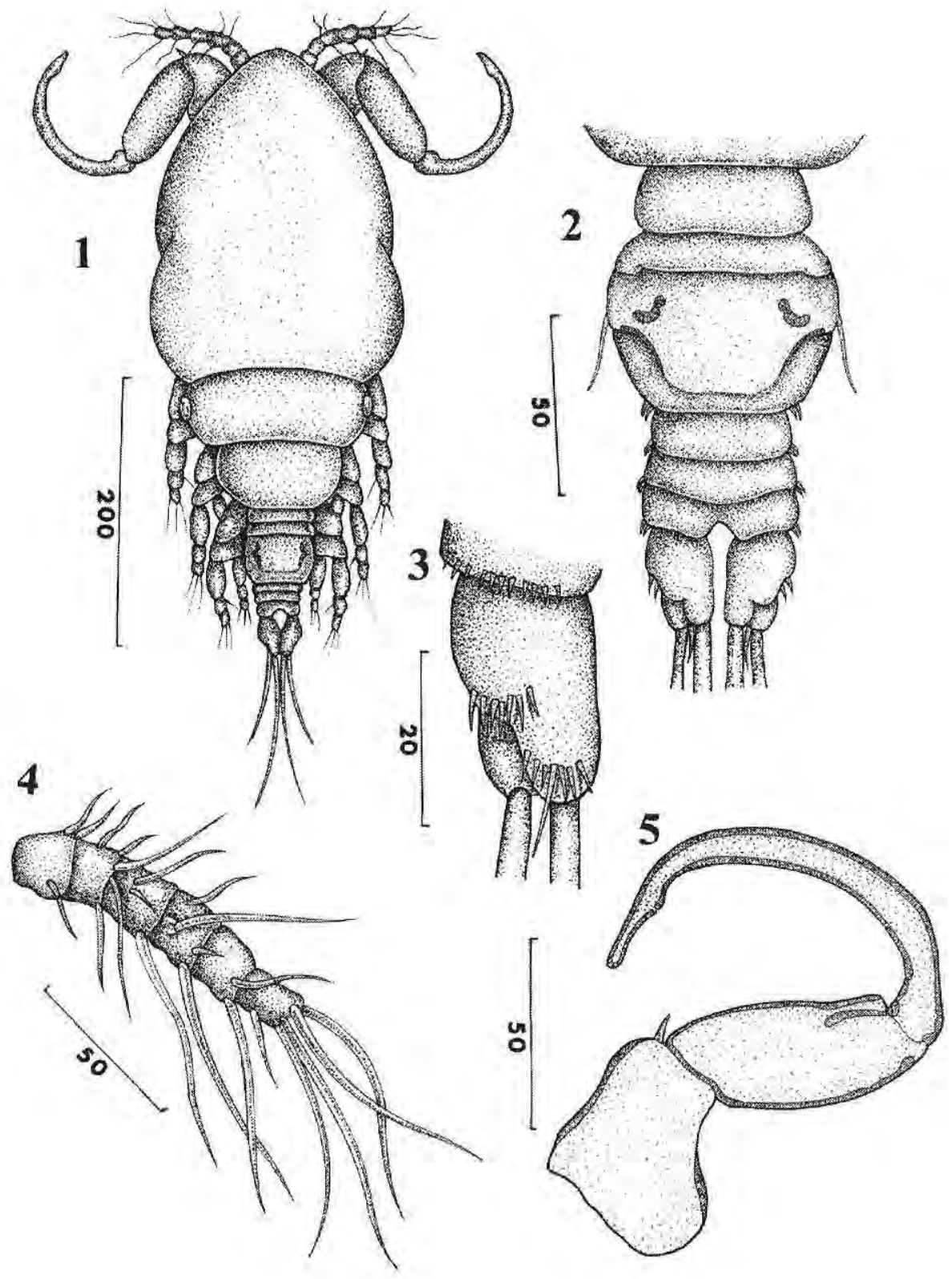

Figures 1-5. Brasergasilus mamorensis sp. n. (female). 1-Dorsal view. 2 - Genital somite, abdomen and uropods. 3 -Detail of the uropod (ventral). 4 -Antennule. 5 -Antenna. 
First three pairs natatory and biramous, with coxopodites having 1 row of spinules on external margin and basipodites with 1 simple seta on outer proximal region. Leg I (Fig. 7). Endopod of two segments, with small spines and bristles on external margin. First segment with four plumose setae and two strong, pectinate spines on distal region. Exopod with three segments, first two segments with two rows of spinules on external margin. First segment with simple distal spine externally and bristles on internal margin. Second segment with plumose median internal seta, and third segment with two strong pectinate spines and five plumose distal setae. Leg II (Fig. 8), both branches with three segments. All endopodal segments with 1 rows of small spinules on external margins. First segment with 1 plumose seta and second segment with two, on internal margin. Third segment with 1 pectinate spine and four plumose distal setae. First exopod segment with bristles on internal margin and 1 simple spine and small spinules on distal region of external margin. Second segment with 1 median internal seta and small spines distal to the external margin. Third segment with 1 spine and six distal plumose setae. Leg III (Fig. 9), differing only by the absence of a larger spine on the first exopod segment. Leg IV lacking. Leg V (Fig. 10) reduced to papilla, with 1 simple seta on each side (vestigial leg) of VI thoracic somite.

Egg sac (Fig. 11), two rows of oval eggs, with an average of 10 eggs in 11 sacs observed.

\section{Male: unknown.}

Etymology: the specific name is derived from the Mamore River where the specimens were collected.

\section{DISCUSSION}

There are four known species of the genus Brasergasilus Thatcher \& Boeger, 1983: B. jaraquensis Thatcher \& Boeger, 1983, collected from the gill filaments of Semaprochilodus insignis (Schomburgk, 1841), in the Solimões River, near Manaus, Amazonas State; B. anodus Thatcher \& Boeger 1983, collected from the gill filaments and gill rakers of Anodus elongatus Spix, 1829 , in the Tocantins River, Pará State; $B$. oranus Thatcher

Table 3. Ornamentation on legs in Brasergasilus mamorensis sp. n., algarism roman refer to spines and arabic to setae.

\begin{tabular}{cll}
\hline & Exopod & Endopod \\
\hline Leg I & $1-0,0-1,1-5$ & $0-1,11-5$ \\
II & $1-0,0-1,1-6$ & $0-1,0-2,1-4$ \\
III & $0-0,0-1,1-6$ & $0-1,0-2,1-4$ \\
\hline
\end{tabular}




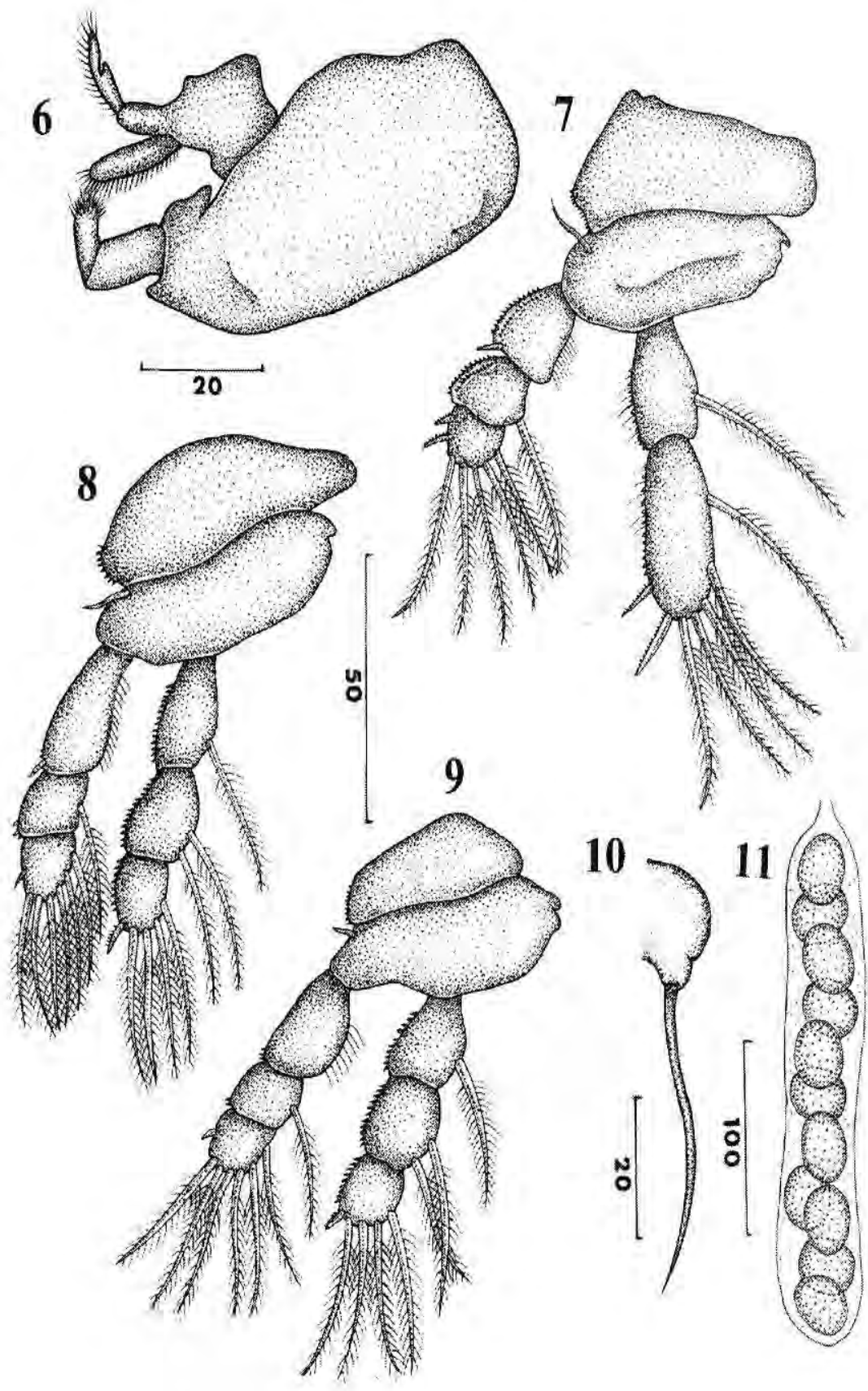

Figures 6-11. Brasergasilus mamorensis sp. n. (female). 6-Mouthparts. 7 - Leg I. 8 - Leg II. 9-Leg III. 10 - Leg V, 11 - Egg sac. 
\& Boeger 1984, collected from the gill tilaments and gill rakers of Anodus elongatus, in the Solimões River, near Manaus; and B. guaporensis Malta, 1995 , collected from the gill filaments of Leporinus fasciatus (Bloch, 1890), the Guaporé River, Rondônia State. aese species of the genus Brasergasilus are endemic to the Neotropical Region (Malta, 1995; Malta \& Varella, 1998).

B. mamorensis sp. $\mathrm{n}$. is the fifth species that has been described for this genus, but it is the first time it has been found in nasal cavities. This is the first report on Hydrolycus pectoralis as a host for Brasergasilus.

Body length measurements of the new species were 432-512 (468), similar to those of $B$. oranus $420-510$ (464), but longer than on $B$. jaraquensis, 340-410 (370), $B$. anodus, 320-370 (354) and $B$. guaporensis, 301-382 (335). The cephalothorax occupies $56 \%$ of the total length, whilst the proportion on other species is $62 \%$ in B. oranus, $55 \%$ in $B$. guaporensis, $53 \%$ in $B$. jaraquensis and $52 \%$ in B. anodus.

This new species is the only one that has: 22 setae in the antenulle, a spine on the first segment of the antenna; coxopodites of all legs with 1 row of spinules on the external margin, and basipodites with 1 simple seta on the outer proximal region; first two segments, of the exopod of leg 1 , with two rows of spinules on the external margin and fifth legs on the sixth thoracic somite.

Malta (1995) described $B$. guaporensis as having the claw of the antenna resembling half an arrow head. This new species has the claws similar to those of B. guaporensis, but the extremity is a little shorter and not so curved. Both species were collected from the same region.

The diagnosis of the subfamily Abergasilinae is: Cyclopidea; Ergasilidae; with the following characters: female with 3 pairs of swimming legs; vestigial legs lacking. Second (prehensile) antenna 3-segmented. The type genus and species is Abergasilus amplexus (Thatcher \& Boeger, 1983).

Hewitt (1978) reported that the female of $A$. amplexus: metasomal segment 4 bears one pair of hairs ventrally, which he had suggested might represent vestigial fourth legs. Jones (1981) redescribed the female of $A$. amplexus and found differences in the mandibles, ornamentation of legs 1-3 and uropods. Jones (1981) described the male of $A$. amplexus, legs 4-5 as for female (female $=$ legs $4-5$ or reduced to setae), leg 6 represented by setae.

The female of B. mamorensis sp. n. has a vestigial leg, (leg 5). The female of A. amplexus (legs 4-5) and male (legs 4-5-6) have vestigial legs too. Two species of this subfamily have vestigial legs. That is why the diagnosis of Abergasilinae reporting vestigial legs lacking, should be changed to: vestigial legs lacking or 1,2 or 3 pairs of vestigial legs present. Another thing that should be changed is the antenna being 2 not 3 -segmented.

We found no specific body adaptations on B. mamorensis sp. $\mathrm{n}$. for liv- 
ing in this new habitat (nasal cavities).

A total of 283 specimens of Brasergasilus mamorensis $\mathrm{sp}$. $\mathrm{n}$, were collected from the nasal cavities of 4 fish (Hydrolycus pectoralis), all from the Mamoré River. The parasitism indexes of the new species were: prevalence $100 \%$; intensity of $14-117$ per host, mean 71 , and density 71 .

\section{Literature cited}

Boxshall, G.A.; Montú, M.A.; Schwarzbold, A. 1997. A new species of Lernaea L. (Copepoda: Cyclopoida) from Brazil, with notes on its ontogeny. Systematic Parasitology, 37:195-205.

Bush, A.O.; Lafferty, K.D.; Lotz, J.M.; Shostak, A.W. 1997. Parasitology meets ecology on its own terms: Margolis et al. Revisited. Journal Parasitology, 83(4):575-583.

Hewitt, G.C. 1978. Abergasilus amplexus gen. et $\mathrm{sp}$. nov. (Ergasilidae: Parasitic Copepoda) from fishes in Lake Ellesmere, New Zealand. New Zealand Journal of Marine and Freshwater Research, 12(2):173-177.

Jones, J.B. 1981. Abergasilus amplexus Hewitt, 1978 (Ergasilidae: Copepoda) from New Zealand, with a description of the male. New Zealand Journal of Marine and Freshwater Research, 15:275-278.

Malta, J.C.O. 1995. Brasergasilus guaporensis sp. n. (Copepoda: Ergasilidae) das brânquias de Leporinus fasciatus (Bloch, 1890) (Characiformes: Anostomidae) da Amazônia Brasileira. Acta Amazonica, 23(4):441-447.
Malta, J.C.O.; Varella, A. 1998. Maxillopoda - Copepoda. Poecilostomatoida. Non-marine Parasites. In: Young, P.S. (Ed.). Catalogue of Crustacea of Brazil. Museu Nacional, Rio de Janeiro, Brasil. P. 241249. (Série Livros no.6).

Margolis, L.; Esch, G.W.; Holmes, J.C.; Kuris, A.M.; Schad, G.A. 1982. The use of ecological terms in Parasitology (Report of an ad hoc Committee of the American Society of parasitologists). Journal of Parasitology, 68(1):131-133.

Thatcher, V.E. 1991. Amazon Fish Parasites. Amazoniana, 11(3):263-572.

Thatcher, V.E. 1998. Copepods and fishes in the Brazilian Amazon. Journal of Marine Systems, 15:97-112.

Thatcher, V.E.; Boeger, W.A. 1983. The parasitic crustaceans of fishes from the Brazilian Amazon. 5. Brasegasilus gen. nov. (Copepoda: Cyclopoidea), a "threelegged" ergasilid, with two new species and the proposal of Abergasilinae subfam. nov. Acta Amazonica, 31:195-214.

Thatcher, V.E.; Boeger, W.A. 1985. The parasitic crustaceans of fishes from the Brazilian Amazon. 6. Brasergasilus oranus n. sp. (Copepoda: Cyclopoidea) from Anodus elongatus Spix. Revista Brasileira de Biologia, 44(4):395-401. 